\title{
Organizational Factors Affecting Employees Retention: A Study on Private Commercial Banks of Bangladesh.
}

\author{
[ Samia Shabnaz, SK. Tasthekur Hossain Kowshik]
}

\begin{abstract}
In the competitive world of business success of any organization depends on high quality service for which retaining valuable and skilled workforce is gradually gaining strategic significance. The nature of work in the banking sector is changing rapidly and that is why the factors that influence employee retention are also shifting. Several studies have been conducted on this topic where most of the researchers focus on the causes of employee turnover. However, this research focused on the organizational factors (Compensations \& Benefits, Career advancement opportunity, Job security, Work place environment, Organization growth and reputation, Relation between top management and employee) that have varying impact on the managerial levels. The study is based on a self-developed questionnaire where Likert Scale was used to collect data from the sample size of 100. . The data analysis was done using SPSS Ver. 20 and Crosstab, frequency table was used to generate results. It has been also found that the priority of these factors differs based on management level. The banks should design their retention programs based on the level of management according to their preferences.
\end{abstract}

Keywords - factors, retention, management level, bank

\section{Introduction}

As the competitiveness of the market is increasing substantially, success of any organization depends on its skilled workforce and retaining valuable employees are becoming major strategic issue for them. Contemporary banking business is emphasizing more on satisfying their employees for retaining their valuable skilled personnel (Islam and Hasan, 2005). The nature of work in the banking sector is changing rapidly and that is why the factors that influence employee retention are also shifting. Excessive employee turnover may cause a key barrier to high quality service so it is necessary to identify the reasons of employee turnover and what the employer can do to retain the best (Branham, 2005).

The banks invests a lot on their employees through job analysis, recruitment \& selection, training, development and a healthy compensation package to ensure retention. Some external factors as well as some organizational factors and personal characteristics and employee's own reaction to his/her job affect the turnover intention (Knowles, 1964).

Samia Shabnaz

American International University- Bangladesh Bangladesh

SK. Tasthekur Hossain Kowshik

American International University- Bangladesh Bangladesh
The banking sector of Bangladesh has considerable contribution on national economy and the industry comprises with four categories of scheduled banks- Stateowned Commercial Banks (SCBs), State-owned Development Financial Institutions (DFIs), Private Commercial Banks (PCBs) and Foreign Commercial Banks (FCBs). To continue to exist in a very competitive environment, the banks need to design effective human resource (HR) practices that encourage the high performance of employees. Several research have been done that focused on the factors influence the retention but very few researchers concentrated on the importance of the factors based on managerial level in the private commercial bank of Bangladesh. So this research focused on in depth understanding about the organizational factors (Compensations \& Benefits, Career advancement opportunity, Job security, Work place environment, Organization growth and reputation, Relation between top management and employee) that have varying impact on the managerial levels. The rest of this paper is organized with a brief literature review on the factors influencing turnover intention, the research methodology and the results of data. Finally the paper concluded with major finding and indicated some future research directions.

\section{Review of Related Literature}

Employees are extremely crucial to the organization since their value to the organization is essentially intangible and not easily replicated (Meaghan \& Nick 2002). Several researchers concentrated on the issue of turnover because turnover has some significant effects on organizations (DeMicco \& Giridharan 1987; Dyke \& Strick 1990; Cantrell \& Saranakhsh 1991; Denvir \& Mcmahon 1992). Many researchers argue that if the organizations don't have the capability to manage high turnover rates than it might have negative effects on profitability (Hogan 1992; Wasmuth \& Davis 1993; Barrows 1990). To be competitive, the firms must retain their competent and motivated employees (Mahmud and Idrish, 2011). So the organization must concentrate on the factors that they have control over influencing turnover.

Researchers analyzed several factors which influence the turnover rate of the employees. Table I summarized the finding and the relationship. Few researches have been done on the context of Bangladesh. Mahmud and Idrish (2011) conducted an empirical study and evaluated six Human Resource (HR) practices (realistic job information, job analysis, work family balance, career development, compensation and supervisor support) and their likely impact on the Employee Intention to Leave (EIL) in the Bangladeshi Banks. Finding of the study indicated that work family balance and employee intention to leave was positively correlated and compensation and job analysis are the most critical HRM practices to be implemented by banks 
to reduce EIL. Similarly Newaz, et.al, (2007) also carried out research on banking sector of Bangladesh and found that employees said that the most important factor for leaving the organization is because their work is unappreciated and not recognized by the organization. In contrast Tanchi (2015) portrayed that some factors such as unattractive pay packages, lack of training and development, partiality and lack of career development influences employee to leave the job but some factors do not influence employee turnover though it seems to be important such as long working hours, lack of job security and work life imbalance etc.

TABLE I. FACTOR INFLUENCING RETENTION

\begin{tabular}{|c|c|c|}
\hline Factors & Researcher & Finding \\
\hline \multirow[t]{5}{*}{ Compensation } & $\begin{array}{l}\text { Park et al. } \\
\text { (1994) Trevor } \\
\text { et al. (1997) }\end{array}$ & $\begin{array}{l}\text { high salary growth significantly } \\
\text { reduced turnover for high } \\
\text { performing employees }\end{array}$ \\
\hline & $\begin{array}{l}\text { Abbasi and } \\
\text { Hollman } \\
(2000)\end{array}$ & $\begin{array}{l}\text { lack of proper recognition and } \\
\text { lack of competitive compensation } \\
\text { system is some reasons for } \\
\text { employee turnover in an } \\
\text { organization. }\end{array}$ \\
\hline & $\begin{array}{l}\text { Gupta \& } \\
\text { Shaw, (2001) }\end{array}$ & $\begin{array}{l}\text { "pay" appear to be the most } \\
\text { critical outcome of organizational } \\
\text { membership for employees. }\end{array}$ \\
\hline & Guyo (2011) & $\begin{array}{l}\text { competitive reward programs and } \\
\text { unfriendly work environment have } \\
\text { influence on turnover rate. }\end{array}$ \\
\hline & $\begin{array}{l}\text { Sutherland } \\
(2002) \text { and } \\
\text { Newaz (2007) }\end{array}$ & $\begin{array}{l}\text { job recognition and appreciation, } \\
\text { desire to return to school, better } \\
\text { paying jobs, unhappiness with the } \\
\text { job and alternative employment } \\
\text { have significance impact on turnover } \\
\text { decision. }\end{array}$ \\
\hline \multirow[t]{4}{*}{ Career Growth } & $\begin{array}{l}\text { Miller and } \\
\text { Wheeler } \\
\text { (1992) }\end{array}$ & $\begin{array}{l}\text { Lack of meaningful work and } \\
\text { opportunities for promotion, } \\
\text { significantly affected employees' } \\
\text { intentions to leave an organization. }\end{array}$ \\
\hline & $\begin{array}{l}\text { Quarles, } \\
\text { (1994). } \\
\text { Dailey \& Kirk } \\
(1992)\end{array}$ & $\begin{array}{l}\text { The evaluation criteria used in the } \\
\text { promotion and reward system also } \\
\text { had significant effects on employees' } \\
\text { turnover intentions }\end{array}$ \\
\hline & $\begin{array}{l}\text { Mahmud and } \\
\text { Idrish, (2011) }\end{array}$ & $\begin{array}{l}\text { Organizations were able to improve } \\
\text { their employees' retention rate by } \\
\text { adopting job enrichment programs } \\
\text { and enhancing their advancement } \\
\text { opportunities }\end{array}$ \\
\hline & $\begin{array}{l}\text { Shija (2011) } \\
\text { Kilumile } \\
\text { (2011) } \\
\text { Hamel and } \\
\text { Breen, 2007) } \\
\end{array}$ & $\begin{array}{l}\text { A need for carrier development as } \\
\text { the leading factors for employee } \\
\text { turnover. }\end{array}$ \\
\hline \multirow[t]{5}{*}{$\begin{array}{l}\text { Employee } \\
\text { relationship } \\
\text { with mgt }\end{array}$} & $\begin{array}{l}\text { Cappelli } \\
(2000)\end{array}$ & $\begin{array}{l}\text { The relationship between managers } \\
\text { and employees influences } \\
\text { employees' decision to staying in } \\
\text { a job. }\end{array}$ \\
\hline & $\begin{array}{l}\text { Newaz, et.al, } \\
(2007)\end{array}$ & $\begin{array}{l}\text { Employees said that the most } \\
\text { important factor for leaving the } \\
\text { organization is lack of appreciation } \\
\text { and recognition by the organization. }\end{array}$ \\
\hline & $\begin{array}{l}\text { Miller and } \\
\text { Wheeler, } \\
\text { (1992). }\end{array}$ & $\begin{array}{l}\text { If the managers show interest in } \\
\text { the well-being of employees and is } \\
\text { supportive and sensitive towards } \\
\text { them emotionally, job satisfaction } \\
\text { level increases }\end{array}$ \\
\hline & $\begin{array}{l}\text { Dailey and } \\
\text { Kirk, (1992) }\end{array}$ & $\begin{array}{l}\text { The length of time that employees } \\
\text { stay in an organization is largely } \\
\text { determined by the relationship } \\
\text { between employees and their } \\
\text { managers }\end{array}$ \\
\hline & $\begin{array}{l}\text { Arokiasamy, } \\
\text { (2013). }\end{array}$ & $\begin{array}{l}\text { Supervisors and managers have an } \\
\text { important impact on employee } \\
\text { turnover }\end{array}$ \\
\hline
\end{tabular}

\begin{tabular}{|l|l|l|}
\hline & $\begin{array}{l}\text { Firth et al. } \\
(2007)\end{array}$ & $\begin{array}{l}\text { Emotional support from supervisors } \\
\text { and self-esteem mediated the impact } \\
\text { of stressors on stress reactions, job } \\
\text { satisfaction, commitment to the } \\
\text { organization and intention to quit. }\end{array}$ \\
\hline Stress & $\begin{array}{l}\text { Bhatti, ashmi and } \\
\text { Hash } \\
\text { Raza (2011) }\end{array}$ & $\begin{array}{l}\text { There was significant negative } \\
\text { relationship between job stress and } \\
\text { job satisfaction }\end{array}$ \\
\hline $\begin{array}{l}\text { Ling, Bahron, } \\
\text { and Boroh } \\
(2014)\end{array}$ & $\begin{array}{l}\text { There is a significant relationship } \\
\text { between role stress and job } \\
\text { satisfaction and gender has a } \\
\text { moderating effect on role stress } \\
\text { towards job satisfaction. }\end{array}$ \\
\hline $\begin{array}{l}\text { Work } \\
\text { Environment: }\end{array}$ & $\begin{array}{l}\text { Shamsuzzoh } \\
\& \\
(2010) \\
\text { Burke and } \\
\text { Hsieh, (2006) }\end{array}$ & $\begin{array}{l}\text { af working conditions are } \\
\text { substandard or the workplace lacks } \\
\text { important facilities such as proper } \\
\text { lighting, furniture, restrooms and } \\
\text { other health and safety provisions, } \\
\text { employees will not be willing to } \\
\text { put up with the inconvenience for } \\
\text { long }\end{array}$ \\
\hline Job security & $\begin{array}{l}\text { Batt } \\
\text { Valcour, } \\
\text { (2003) }\end{array}$ & $\begin{array}{l}\text { There are some empirical } \\
\text { evidences that show a significant } \\
\text { negative relationship between } \\
\text { turnover intention and job security }\end{array}$ \\
\hline $\begin{array}{l}\text { Samuel and } \\
\text { Chipunza } \\
\text { (2009), }\end{array}$ & $\begin{array}{l}\text { According to Samuel and Chipunza } \\
\text { (2009), job security was found to be } \\
\text { significantly influencing factor in } \\
\text { employee retention in both public } \\
\text { and private organizations. }\end{array}$ \\
\hline
\end{tabular}

\section{Methodology of the Study}

The research was conducted on private commercial banks of Bangladesh by concentrating on the organizational factors (compensation, career growth, employee relation with management, stress, work environment, job security) affecting Employee's retention. Both primary and secondary data has been collected. The sample of the study was taken from the five different banks (Midland Bank Limited Meghna Bank Limited, BRAC Bank Limited, Social Islami Bank Ltd, Pubali Bank Limited) in Dhaka City which was randomly selected. As total population is not accessible the study implemented non-probability convenience sampling and 100 employees were taken as sample size. To collect primary data a self-designed questionnaire with 29 questions was used and distributed to different managerial levels. The data analysis was done using SPSS version 20 and Crosstab, frequency table was used to generate results.

\section{A. Reliability Test}

As the questionnaire used for data collection was designed rather than adopted from an existing research, a reliability test was thought necessary. The Cronbach Alpha testing was used as it is the most well accepted reliability test tools applied by social researcher (Sekaran, 2003). The closer Cronbach's Alpha is to 1.0, the higher is the internal consistency reliability. Cronbach measures indicates that if the reliability is more than 0.8 than it is considered to be good. The questionnaire used in this research is considered acceptable as its value mentioned in Table II are more than 0.80 .

TABLE II. RELIABILITY STATISTICS

\begin{tabular}{|l|l|}
\hline Cronbach's Alpha & N of Items \\
\hline .899 & 34 \\
\hline
\end{tabular}


Table III represents that the non-financial benefits are important for every level of employees to create their loyalty to the organization. The top level employees $(92.9 \%)$ and entry level employees $(88.6 \%)$ emphasized more than midlevel employees $(76.5 \%)$. The significance of this is also visible in the chi square test $\left(\mathrm{X}^{\wedge} 2=12.859, \mathrm{df}=6, \mathrm{p}=0.045\right)$.

TABLE III. MANAGEMENT LEVEL AND THE NON-FINANCIAL BENEFITS (HEALTH, INSURANCE, BENEFITS, ETC.)

\begin{tabular}{|c|c|c|c|c|c|c|c|}
\hline & & & D & $\mathrm{N}$ & A & S A & $\mathrm{T}$ \\
\hline \multirow[t]{3}{*}{$\begin{array}{l}\text { Mgt } \\
\text { Level }\end{array}$} & $\begin{array}{l}\text { Top } \\
\text { Level }\end{array}$ & $\begin{array}{l}\text { Count } \\
\% \text { within Mgt } \\
\text { Level }\end{array}$ & $\begin{array}{l}0 \\
.0 \%\end{array}$ & $\begin{array}{l}1 \\
7.1 \%\end{array}$ & $\begin{array}{l}4 \\
28.6 \%\end{array}$ & $\begin{array}{l}9 \\
64.3 \%\end{array}$ & $\begin{array}{l}14 \\
100.0 \%\end{array}$ \\
\hline & $\begin{array}{l}\text { Middle } \\
\text { Level }\end{array}$ & $\begin{array}{l}\text { Count } \\
\% \text { within } \mathrm{Mgt} \\
\text { Level }\end{array}$ & $\begin{array}{l}1 \\
2.0 \%\end{array}$ & $\begin{array}{l}11 \\
21.6 \%\end{array}$ & $\begin{array}{l}28 \\
54.9 \%\end{array}$ & $\begin{array}{l}11 \\
21.6 \%\end{array}$ & $\begin{array}{l}51 \\
100.0 \%\end{array}$ \\
\hline & $\begin{array}{l}\text { Entry } \\
\text { Level }\end{array}$ & $\begin{array}{l}\text { Count } \\
\% \text { within Mgt } \\
\text { Level }\end{array}$ & $\begin{array}{l}1 \\
2.9 \%\end{array}$ & $\begin{array}{l}3 \\
8.6 \%\end{array}$ & $\begin{array}{l}14 \\
40.0 \%\end{array}$ & $\begin{array}{l}17 \\
48.6 \%\end{array}$ & $\begin{array}{l}35 \\
100.0 \%\end{array}$ \\
\hline Total & & $\begin{array}{l}\text { Count } \\
\% \text { within } \mathrm{Mgt} \\
\text { Level }\end{array}$ & $\begin{array}{l}2 \\
2.0 \%\end{array}$ & $\begin{array}{l}15 \\
15.0 \%\end{array}$ & $\begin{array}{l}46 \\
46.0 \%\end{array}$ & $\begin{array}{l}37 \\
37.0 \%\end{array}$ & $\begin{array}{l}100 \\
100.0 \%\end{array}$ \\
\hline
\end{tabular}

Table IV portrays that a large number of top level employees are satisfied $(92.9 \%)$ with the bonus whereas only $(28.6 \%)$ entry level employees and (41.2) midlevel employees were satisfied. Based on The relationship is also significant which is apparent from the Chi square test $\left(\mathrm{X}^{\wedge} 2=37.320, \mathrm{df}=8, \mathrm{p}=0.000\right)$

TABLE IV. MANAGEMENT LEVEL AND THE AMOUNT OF BONUS

\begin{tabular}{|c|c|c|c|c|c|c|c|c|}
\hline & & & SD & D & $\mathrm{N}$ & A & SA & $\mathrm{T}$ \\
\hline \multirow[t]{3}{*}{$\begin{array}{l}\text { Mgt } \\
\text { Level }\end{array}$} & $\begin{array}{l}\text { Top } \\
\text { Level }\end{array}$ & $\begin{array}{l}\text { Count } \\
\% \quad \text { within } \\
\text { Mgt Level }\end{array}$ & $\begin{array}{l}0 \\
.0 \%\end{array}$ & $\begin{array}{l}0 \\
.0 \%\end{array}$ & $\begin{array}{l}1 \\
7.1 \%\end{array}$ & $\begin{array}{l}5 \\
35.7 \%\end{array}$ & $\begin{array}{l}8 \\
57.1 \%\end{array}$ & $\begin{array}{l}14 \\
100.0 \\
\%\end{array}$ \\
\hline & $\begin{array}{l}\text { Middle } \\
\text { Level }\end{array}$ & $\begin{array}{l}\text { Count } \\
\% \quad \text { within } \\
\text { Mgt Level }\end{array}$ & $\begin{array}{l}0 \\
.0 \%\end{array}$ & $\begin{array}{l}10 \\
19.6 \\
\%\end{array}$ & $\begin{array}{l}20 \\
39.2 \%\end{array}$ & $\begin{array}{l}16 \\
31.4 \%\end{array}$ & $\begin{array}{l}5 \\
9.8 \%\end{array}$ & $\begin{array}{l}51 \\
100.0 \\
\%\end{array}$ \\
\hline & $\begin{array}{l}\text { Entry } \\
\text { Level }\end{array}$ & $\begin{array}{l}\text { Count } \\
\% \quad \text { within } \\
\text { Mgt Level }\end{array}$ & $\begin{array}{l}3 \\
8.6 \%\end{array}$ & $\begin{array}{l}2 \\
5.7 \%\end{array}$ & $\begin{array}{l}20 \\
57.1 \%\end{array}$ & $\begin{array}{l}8 \\
22.9 \%\end{array}$ & $\begin{array}{l}2 \\
5.7 \%\end{array}$ & $\begin{array}{l}35 \\
100.0 \\
\%\end{array}$ \\
\hline Total & & $\begin{array}{l}\text { Count } \\
\% \quad \text { within } \\
\text { Mgt Level }\end{array}$ & & $\begin{array}{l}12 \\
12.0 \\
\%\end{array}$ & $\begin{array}{l}41 \\
41.0 \%\end{array}$ & $\begin{array}{l}29 \\
29.0 \%\end{array}$ & $\begin{array}{l}15 \\
15.0 \%\end{array}$ & $\begin{array}{l}100 \\
100.0 \\
\%\end{array}$ \\
\hline
\end{tabular}

It is observed from table $\mathrm{V}$ that a significant number of top level employees $(78.5 \%)$ believe that the process is fair but the percentage is lower for mid-level $(35.3 \%)$ and the entry level employee (31.5\%). Moreover the relationship is also significant which is apparent in the Chi-Square Test $\left(\mathrm{X}^{\wedge} 2=42.182, \mathrm{df}=8, \mathrm{p}=0.000\right)$

In relation to table IV and $\mathrm{V}$ the table VI also indicates that only $29.4 \%$ mid-level employees and $14.3 \%$ entry level employees are satisfied with their annual increment but at the same time $85.7 \%$ top level employees are satisfied. The significance of this relationship is also evident from the Chi square test $\left(\mathrm{X}^{\wedge} 2=46.032, \mathrm{df}=8, \mathrm{p}=0.000\right)$

The information from table VII shows that very few entry level employees $(25.7 \%)$ and mid-level level employees $(19.6 \%)$ satisfied about the initiatives taken by the bank for career advancement whereas the percentage is high for top level employees (78.6\%). The relationship is also significant which is apparent from the Chi square test $\left(X^{\wedge} 2=26.414, d f=8, p=0.001\right)$

TABLE V. MANAGEMENT LEVEl AND THE Process USED To DETERMINE ANNUAL RAISES

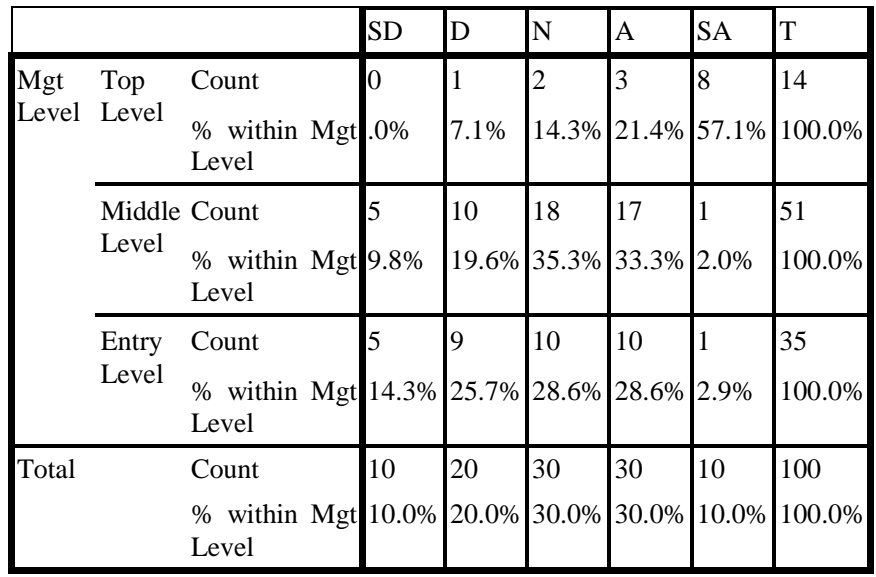

TABLE VI. MANAGEMENT LEVEL AND ANNUAL INCREMENT.

\begin{tabular}{|c|c|c|c|c|c|c|c|c|}
\hline & & & SD & D & $\mathrm{N}$ & A & SA & $\mathrm{T}$ \\
\hline \multirow{6}{*}{$\begin{array}{l}\text { Mgt } \\
\text { Level }\end{array}$} & \multirow{2}{*}{$\begin{array}{c}\text { Top } \\
\text { Level }\end{array}$} & Count & 1 & 1 & 0 & 4 & 8 & 14 \\
\hline & & $\begin{array}{c}\% \text { within Mgt } \\
\text { Level }\end{array}$ & $7.1 \%$ & $7.1 \%$ & $.0 \%$ & $28.6 \%$ & $57.1 \%$ & $100.0 \%$ \\
\hline & \multirow{2}{*}{$\begin{array}{l}\text { Middle } \\
\text { Level }\end{array}$} & Count & 14 & 13 & 9 & 13 & 2 & 51 \\
\hline & & $\begin{array}{c}\% \text { within Mgt } \\
\text { Level }\end{array}$ & $27.5 \%$ & $25.5 \%$ & $17.6 \%$ & $25.5 \%$ & $3.9 \%$ & $100.0 \%$ \\
\hline & \multirow{2}{*}{$\begin{array}{l}\text { Entry } \\
\text { Level }\end{array}$} & Count & 10 & 12 & 8 & 5 & 0 & 35 \\
\hline & & $\begin{array}{c}\% \text { within Mgt } \\
\text { Level }\end{array}$ & $28.6 \%$ & $34.3 \%$ & $22.9 \%$ & $14.3 \%$ & $.0 \%$ & $100.0 \%$ \\
\hline \multirow{2}{*}{\multicolumn{2}{|c|}{ Total }} & Count & 25 & 26 & 17 & 22 & 10 & 100 \\
\hline & & $\begin{array}{c}\% \text { within Mgt } \\
\text { Level }\end{array}$ & $25.0 \%$ & $26.0 \%$ & $17.0 \%$ & $22.0 \%$ & $10.0 \%$ & $100.0 \%$ \\
\hline
\end{tabular}

TABLE VII. MANAGEMENT LEVEl AND CAREER Potential.

\begin{tabular}{|c|c|c|c|c|c|c|c|}
\hline & & SD & D & $\mathrm{N}$ & A & SA & $\mathrm{T}$ \\
\hline \multirow{6}{*}{$\begin{array}{l}\text { Mgt } \\
\text { Level }\end{array}$} & Count & 1 & 1 & 1 & 6 & 5 & 14 \\
\hline & $\begin{array}{l}\% \text { within } \mathrm{Mgt} \\
\text { Level }\end{array}$ & $7.1 \%$ & $7.1 \%$ & $7.1 \%$ & $42.9 \%$ & $35.7 \%$ & $100.0 \%$ \\
\hline & Count & 13 & 14 & 14 & 5 & 5 & 51 \\
\hline & $\begin{array}{l}\text { \% within Mgt } \\
\text { Level }\end{array}$ & $25.5 \%$ & $27.5 \%$ & $27.5 \%$ & $9.8 \%$ & $9.8 \%$ & $100.0 \%$ \\
\hline & Count & 6 & 12 & 8 & 9 & 0 & 35 \\
\hline & $\begin{array}{l}\% \text { within } \mathrm{Mgt} \\
\text { Level }\end{array}$ & $17.1 \%$ & $34.3 \%$ & $22.9 \%$ & $25.7 \%$ & $.0 \%$ & $100.0 \%$ \\
\hline \multirow[t]{2}{*}{ Total } & Count & 20 & 27 & 23 & 20 & 10 & 100 \\
\hline & $\begin{array}{l}\% \text { within } \mathrm{Mgt} \\
\text { Level }\end{array}$ & $20.0 \%$ & $27.0 \%$ & $23.0 \%$ & $20.0 \%$ & $10.0 \%$ & $100.0 \%$ \\
\hline
\end{tabular}

From table VIII it is observed that the top level employees $(78.6 \%)$ mostly responded on the favor that the organization helped them to gather more experience whereas it is much less for mid-level $(33.3 \%)$ and entry level employees $(42.9 \%)$. The relationship is also significant which is apparent from the Chi square test $\left(\mathrm{X}^{\wedge} 2=21.770, \mathrm{df}=\right.$ $8, \mathrm{p}=0.005$ ) 
Proc. of Sixth International Conference On Advances in Economics, Management and Social Study - EMS 2016. Copyright (c) Institute of Research Engineers and Doctors. All rights reserved.

ISBN no. 978-1-63248-111-5 doi: 10.15224/ 978-1-63248-111-5-30

TABLE VIII. MANAGEMENT LEVEL AND OPPORTUNITY FOR GAINING EXPERIENCE

\begin{tabular}{|c|c|c|c|c|c|c|c|c|}
\hline & & & SD & D & $\mathrm{N}$ & A & SA & $\mathrm{T}$ \\
\hline \multirow[t]{3}{*}{$\begin{array}{l}\text { Mgt } \\
\text { Level }\end{array}$} & $\begin{array}{l}\text { Top } \\
\text { Level }\end{array}$ & $\begin{array}{l}\text { Count } \\
\% \text { within Mgt } \\
\text { Level }\end{array}$ & $\begin{array}{l}1 \\
7.1 \%\end{array}$ & $\begin{array}{l}1 \\
7.1 \%\end{array}$ & $\begin{array}{l}1 \\
7.1 \%\end{array}$ & $\begin{array}{l}5 \\
35.7 \%\end{array}$ & $\begin{array}{l}6 \\
42.9 \%\end{array}$ & $\begin{array}{l}14 \\
100.0 \%\end{array}$ \\
\hline & $\begin{array}{l}\text { Middle } \\
\text { Level }\end{array}$ & $\begin{array}{l}\text { Count } \\
\text { \% within Mgt } \\
\text { Level }\end{array}$ & $\begin{array}{l}2 \\
3.9 \%\end{array}$ & $\begin{array}{l}8 \\
15.7 \%\end{array}$ & $\begin{array}{l}24 \\
47.1 \%\end{array}$ & $\begin{array}{l}15 \\
29.4 \%\end{array}$ & $\begin{array}{l}2 \\
3.9 \%\end{array}$ & $\begin{array}{l}51 \\
100.0 \%\end{array}$ \\
\hline & $\begin{array}{l}\text { Entry } \\
\text { Level }\end{array}$ & $\begin{array}{l}\text { Count } \\
\% \text { within Mgt } \\
\text { Level }\end{array}$ & $\begin{array}{l}3 \\
8.6 \%\end{array}$ & $\begin{array}{l}4 \\
11.4 \%\end{array}$ & $\begin{array}{l}13 \\
37.1 \%\end{array}$ & $\begin{array}{l}12 \\
34.3 \%\end{array}$ & $\begin{array}{l}3 \\
8.6 \%\end{array}$ & $\begin{array}{l}35 \\
100.0 \%\end{array}$ \\
\hline Total & & $\begin{array}{l}\text { Count } \\
\text { \% within Mgt } \\
\text { Level }\end{array}$ & $\begin{array}{l}6 \\
6.0 \%\end{array}$ & $\begin{array}{l}13 \\
13.0 \%\end{array}$ & $\begin{array}{l}38 \\
38.0 \%\end{array}$ & $\begin{array}{l}32 \\
32.0 \%\end{array}$ & $\begin{array}{l}11 \\
11.0 \%\end{array}$ & $\begin{array}{l}100 \\
100.0 \%\end{array}$ \\
\hline
\end{tabular}

In relation to table VII, the table IX also indicates that less number of mid-level $(19.6 \%)$ and entry level $(25.8 \%)$ employees think that their organizations are supportive to their long-term career development compared to top level employees $(78.6 \%)$. Moreover the relationship is also significant which is apparent in the Chi-Square Test $\left(\mathrm{X}^{\wedge} 2=\right.$ $30.098, \mathrm{df}=8, \mathrm{p}=0.000$ )

TABLE IX. MANAGEMENT LEVEL AND LONG-TERM CAREER DEVELOPMENT OPPORTUNITY

\begin{tabular}{|c|c|c|c|c|c|c|c|c|}
\hline & & & SD & D & $\mathrm{N}$ & A & SA & $\mathrm{T}$ \\
\hline \multirow[t]{3}{*}{$\begin{array}{l}\text { Mgt } \\
\text { Level }\end{array}$} & $\begin{array}{l}\text { Top } \\
\text { Level }\end{array}$ & $\begin{array}{l}\text { Count } \\
\% \text { within } \mathrm{Mgt} \\
\text { Level }\end{array}$ & $\begin{array}{l}0 \\
.0 \%\end{array}$ & $\begin{array}{l}2 \\
14.3 \%\end{array}$ & $\begin{array}{l}1 \\
7.1 \%\end{array}$ & $\begin{array}{l}6 \\
42.9 \%\end{array}$ & $\begin{array}{l}5 \\
35.7 \%\end{array}$ & $\begin{array}{l}14 \\
100.0 \%\end{array}$ \\
\hline & $\begin{array}{l}\text { Middle } \\
\text { Level }\end{array}$ & $\begin{array}{l}\text { Count } \\
\% \text { within Mgt } \\
\text { Level }\end{array}$ & $\begin{array}{l}12 \\
23.5 \%\end{array}$ & $\begin{array}{l}20 \\
39.2 \%\end{array}$ & $\begin{array}{l}9 \\
17.6 \%\end{array}$ & $\begin{array}{l}9 \\
17.6 \%\end{array}$ & $\begin{array}{l}1 \\
2.0 \%\end{array}$ & $\begin{array}{l}51 \\
100.0 \%\end{array}$ \\
\hline & $\begin{array}{l}\text { Entry } \\
\text { Level }\end{array}$ & $\begin{array}{l}\text { Count } \\
\% \text { within Mgt } \\
\text { Level }\end{array}$ & $\begin{array}{l}8 \\
22.9 \%\end{array}$ & $\begin{array}{l}9 \\
25.7 \%\end{array}$ & $\begin{array}{l}9 \\
25.7 \%\end{array}$ & $\begin{array}{l}8 \\
22.9 \%\end{array}$ & $\begin{array}{l}1 \\
2.9 \%\end{array}$ & $\begin{array}{l}35 \\
100.0 \%\end{array}$ \\
\hline \multicolumn{2}{|l|}{ Total } & $\begin{array}{l}\text { Count } \\
\% \text { within Mgt } \\
\text { Level }\end{array}$ & $\begin{array}{l}20 \\
20.0 \%\end{array}$ & $\left|\begin{array}{l}31 \\
31.0 \%\end{array}\right|$ & $\begin{array}{l}19 \\
19.0 \%\end{array}$ & $\begin{array}{l}23 \\
23.0 \%\end{array}$ & $\begin{array}{l}7 \\
7.0 \%\end{array}$ & $\begin{array}{l}100 \\
100.0 \%\end{array} \mid$ \\
\hline
\end{tabular}

Table X portrays that a large number $(78.6 \%)$ of top level employees believe that their organization give the opportunity for career progression whereas the percentage is low for Mid-level (43.1\%) and entry level (28.60\%) employees. The significance of this relationship is also evident from the Chi square test $\left(\mathrm{X}^{\wedge} 2=25.062, \mathrm{df}=8\right.$, $\mathrm{p}=0.002$ )

A significant difference in employees' belief about the process used to determine promotion varies based on management level which evident in table XI. It is high for top level employees (78.6\%) but low for mid-level (27.4\%) and the entry level $(25.8 \%)$ employees. Moreover, the relationship is also significant which is apparent in the ChiSquare Test $\left(\mathrm{X}^{\wedge} 2=18.425, \mathrm{df}=8, \mathrm{p}=0.018\right)$

Table XII represents that top-level $(71.5 \%)$ employees feel that their job is secured but on the other hand it is low for entry level (48.6\%) and mid-level (21.6\%) employees. The relationship is also significant which is apparent from the Chi square test $\left(\mathrm{X}^{\wedge} 2=20.103, \mathrm{df}=8, \mathrm{p}=0.010\right)$.
TABLE X. MANAGEMENT LEVEl AND CAREER PRogression OPPORTUNITIES

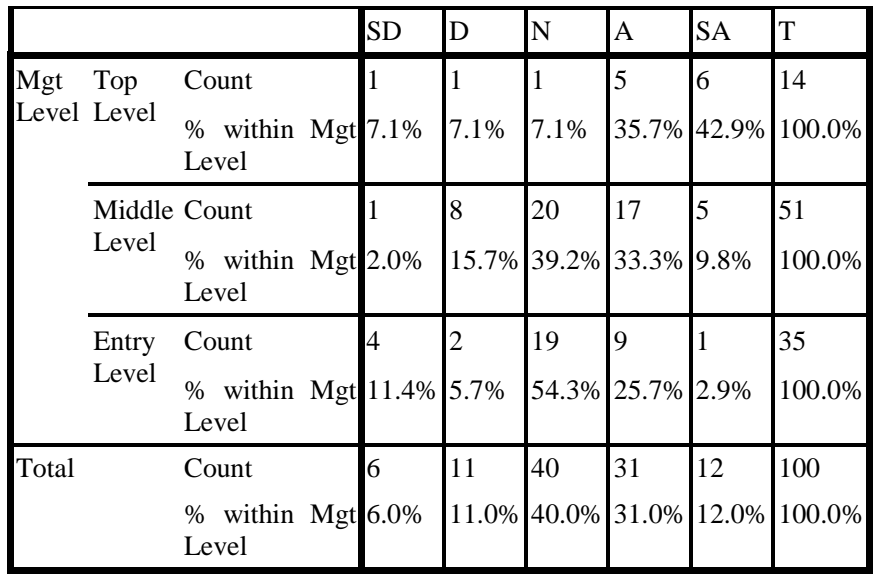

TABLE XI. MANAGEMENT LEVEL AND THE PRocess USED To DETERMINE PROMOTIONS

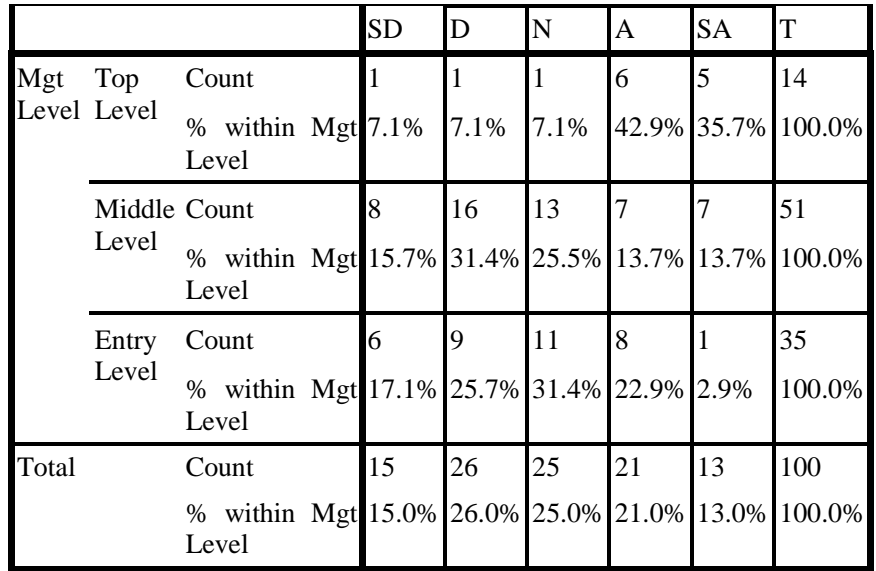

TABLE XII. MANAGEMENT LEVEL AND THE JoB SECURITY

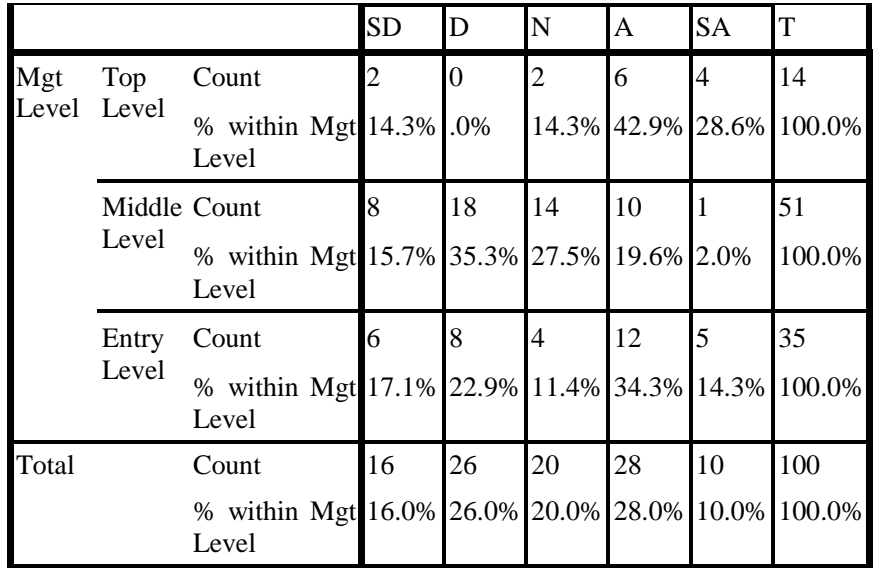

The information from table XIII represents that almost every level employees are satisfied with the physical working condition as the percentage is $78.6 \%$ for top level employees, $62.8 \%$ mid-level employees and $62.9 \%$ for entry level employees. Moreover, the relationship is also significant which is apparent in the Chi-Square Test $\left(\mathrm{X}^{\wedge} 2=\right.$ $16.584, \mathrm{df}=8, \mathrm{p}=0.035$ )

From table XIV represents that $85.7 \%$ top level employees are satisfied with the level of security in their respective organizations whereas $60.7 \%$ mid-level employees and $57.1 \%$ entry level employees have agreed with the statement. Moreover the relationship is also 
significant which is apparent in the Chi-Square Test $\left(\mathrm{X}^{\wedge} 2=\right.$ $13.974, \mathrm{df}=6, \mathrm{p}=0.030$ )

TABLE XIII. MANAGEMENT LEVEL AND THE PhySICAL WoRKING CONDITIONS

\begin{tabular}{|c|c|c|c|c|c|c|c|c|}
\hline & & & SD & D & $\mathrm{N}$ & A & SA & $\mathrm{T}$ \\
\hline \multirow[t]{3}{*}{$\begin{array}{l}\text { Mgt } \\
\text { Level }\end{array}$} & $\begin{array}{l}\text { Top } \\
\text { Level }\end{array}$ & $\begin{array}{l}\text { Count } \\
\% \text { within Mgt } \\
\text { Level }\end{array}$ & $\begin{array}{l}0 \\
.0 \%\end{array}$ & $\begin{array}{l}0 \\
.0 \%\end{array}$ & $\begin{array}{l}3 \\
21.4 \%\end{array}$ & $\begin{array}{l}7 \\
50.0 \%\end{array}$ & $\begin{array}{l}4 \\
28.6 \%\end{array} \mid$ & $\begin{array}{l}14 \\
100.0 \%\end{array}$ \\
\hline & $\begin{array}{l}\text { Middle } \\
\text { Level }\end{array}$ & $\begin{array}{l}\text { Count } \\
\text { \% within Mgt } \\
\text { Level }\end{array}$ & $\begin{array}{l}1 \\
2.0 \%\end{array}$ & $\begin{array}{l}3 \\
5.9 \%\end{array}$ & $\begin{array}{l}15 \\
29.4 \%\end{array}$ & $\begin{array}{l}31 \\
60.8 \%\end{array}$ & $\begin{array}{l}1 \\
2.0 \%\end{array}$ & $\mid \begin{array}{l}51 \\
100.0 \%\end{array}$ \\
\hline & $\begin{array}{l}\text { Entry } \\
\text { Level }\end{array}$ & $\begin{array}{l}\text { Count } \\
\% \text { within Mgt } \\
\text { Level }\end{array}$ & $\begin{array}{l}2 \\
5.7 \%\end{array}$ & $\begin{array}{l}5 \\
14.3 \%\end{array}$ & $\begin{array}{l}6 \\
17.1 \%\end{array}$ & $\begin{array}{l}15 \\
42.9 \%\end{array}$ & $\begin{array}{l}7 \\
20.0 \%\end{array}$ & $\begin{array}{l}35 \\
100.0 \%\end{array}$ \\
\hline Total & & $\begin{array}{l}\text { Count } \\
\% \text { within Mgt } \\
\text { Level }\end{array}$ & $\begin{array}{l}3 \\
3.0 \%\end{array}$ & $\begin{array}{l}8 \\
8.0 \%\end{array}$ & $\begin{array}{l}24 \\
24.0 \%\end{array}$ & $\begin{array}{l}53 \\
53.0 \%\end{array}$ & $\begin{array}{l}12 \\
12.0 \%\end{array}$ & $\begin{array}{l}100 \\
100.0 \%\end{array}$ \\
\hline
\end{tabular}

TABLE XIV. MANAGEMENT LEVEL AND SECURITY IN THE ORGANIZATION

\begin{tabular}{|c|c|c|c|c|c|c|c|}
\hline & & & $\mathrm{D}$ & $\mathrm{N}$ & A & SA & $\mathrm{T}$ \\
\hline Mgt Level & Top & Count & 0 & 2 & 8 & 4 & 14 \\
\hline & Level & $\%$ within Mgt Level & $.0 \%$ & $\begin{array}{l}14.3 \\
\%\end{array}$ & $\begin{array}{l}57.1 \\
\%\end{array}$ & $\begin{array}{l}28.6 \\
\%\end{array}$ & $\begin{array}{l}100.0 \\
\%\end{array}$ \\
\hline & Middle & Count & 1 & 19 & 27 & 4 & 51 \\
\hline & & $\%$ within Mgt Level & $\begin{array}{l}2.0 \\
\%\end{array}$ & $\begin{array}{l}37.3 \\
\%\end{array}$ & $\begin{array}{l}52.9 \\
\%\end{array}$ & $\begin{array}{l}7.8 \\
\%\end{array}$ & $\begin{array}{l}100.0 \\
\%\end{array}$ \\
\hline & Entry & Count & 5 & 10 & 18 & 2 & 35 \\
\hline & & $\%$ within Mgt Level & $\begin{array}{l}14.3 \\
\%\end{array}$ & $\begin{array}{l}28.6 \\
\%\end{array}$ & $\begin{array}{l}51.4 \\
\%\end{array}$ & $\begin{array}{l}5.7 \\
\%\end{array}$ & $\begin{array}{l}100.0 \\
\%\end{array}$ \\
\hline Total & & Count & 6 & 31 & 53 & 10 & 100 \\
\hline & & $\%$ within Mgt Level & $\begin{array}{l}6.0 \\
\%\end{array}$ & $\begin{array}{l}31.0 \\
\%\end{array}$ & $\begin{array}{l}53.0 \\
\%\end{array}$ & $\begin{array}{l}10.0 \\
\%\end{array}$ & $\begin{array}{l}100.0 \\
\%\end{array}$ \\
\hline
\end{tabular}

TABLE XV. MANAGEMENT LEVEL AND SPIRIT OF COOPERATION AND TEAMWORK IN THE ORGANIZATION.

\begin{tabular}{|c|c|c|c|c|c|c|c|c|}
\hline & & & SD & D & $\mathrm{N}$ & A & SA & $\mathrm{T}$ \\
\hline \multirow[t]{3}{*}{$\begin{array}{l}\text { Mgt } \\
\text { Level }\end{array}$} & $\begin{array}{l}\text { Top } \\
\text { Level }\end{array}$ & $\begin{array}{l}\text { Count } \\
\% \text { within } \mathrm{Mgt} \\
\text { Level }\end{array}$ & $\begin{array}{l}0 \\
.0 \%\end{array}$ & $\begin{array}{l}0 \\
.0 \%\end{array}$ & $\begin{array}{l}2 \\
14.3 \%\end{array}$ & $\begin{array}{l}8 \\
57.1 \%\end{array}$ & $\begin{array}{l}4 \\
28.6 \%\end{array}$ & $\begin{array}{l}14 \\
100.0 \%\end{array}$ \\
\hline & $\begin{array}{l}\text { Middle } \\
\text { Level }\end{array}$ & $\begin{array}{l}\text { Count } \\
\% \text { within Mgt } \\
\text { Level }\end{array}$ & $\begin{array}{l}0 \\
.0 \%\end{array}$ & $\begin{array}{l}4 \\
7.8 \%\end{array}$ & $\begin{array}{l}19 \\
37.3 \%\end{array}$ & $\begin{array}{l}26 \\
51.0 \%\end{array}$ & $\begin{array}{l}2 \\
3.9 \%\end{array}$ & $\begin{array}{l}51 \\
100.0 \%\end{array}$ \\
\hline & $\begin{array}{l}\text { Entry } \\
\text { Level }\end{array}$ & $\begin{array}{l}\text { Count } \\
\% \text { within Mgt } \\
\text { Level }\end{array}$ & $\begin{array}{l}1 \\
2.9 \%\end{array}$ & $\begin{array}{l}6 \\
17.1 \%\end{array}$ & $\begin{array}{l}6 \\
17.1 \%\end{array}$ & $\begin{array}{l}19 \\
54.3 \%\end{array}$ & $\begin{array}{l}3 \\
8.6 \%\end{array}$ & $\mid \begin{array}{l}35 \\
100.0 \%\end{array}$ \\
\hline Total & & $\begin{array}{l}\text { Count } \\
\% \text { within } \mathrm{Mgt} \\
\text { Level }\end{array}$ & $\begin{array}{l}1 \\
1.0 \%\end{array}$ & $\begin{array}{l}10 \\
10.0 \%\end{array}$ & $\begin{array}{l}27 \\
27.0 \%\end{array}$ & $\begin{array}{l}53 \\
53.0 \%\end{array}$ & $\begin{array}{l}9 \\
9.0 \%\end{array}$ & $\begin{array}{l}100 \\
100.0 \%\end{array}$ \\
\hline
\end{tabular}

The information from table XV represents that $85.7 \%$ top level employees agreed that there is cooperation and teamwork exist in the organization which is higher than that of mid-level $(54.9 \%)$ and entry level $(62.9 \%)$ employees. Moreover the relationship is also significant which is apparent in the Chi-Square Test $\left(\mathrm{X}^{\wedge} 2=16.887, \mathrm{df}=8\right.$, $\mathrm{p}=0.031$
TABLE XVI. MANAGEMENT LEVEL AND INTENTION TO STAY BECAUSE OF ORGANIZATIONAL REPUTATION

\begin{tabular}{|c|c|c|c|c|c|c|c|c|}
\hline & & & SD & D & $\mathrm{N}$ & A & SA & $\mathrm{T}$ \\
\hline $\begin{array}{l}\text { Mgt } \\
\text { Level }\end{array}$ & $\begin{array}{l}\text { Top } \\
\text { Level }\end{array}$ & $\begin{array}{l}\text { Count } \\
\text { \% within Mgt } \\
\text { Level }\end{array}$ & $\begin{array}{l}0 \\
.0 \%\end{array}$ & $\begin{array}{l}0 \\
.0 \%\end{array}$ & $\begin{array}{l}3 \\
21.4 \%\end{array}$ & $\begin{array}{l}7 \\
50.0 \%\end{array}$ & $\begin{array}{l}4 \\
28.6 \%\end{array}$ & $\begin{array}{l}14 \\
100.0 \%\end{array}$ \\
\hline & $\begin{array}{l}\text { Middle } \\
\text { Level }\end{array}$ & $\begin{array}{l}\text { Count } \\
\text { \% within Mgt } \\
\text { Level }\end{array}$ & $\begin{array}{l}2 \\
3.9 \%\end{array}$ & $\begin{array}{l}6 \\
11.8 \%\end{array}$ & $\begin{array}{l}23 \\
45.1 \%\end{array}$ & $\begin{array}{l}15 \\
29.4 \%\end{array}$ & $\begin{array}{l}5 \\
9.8 \%\end{array}$ & $\begin{array}{l}51 \\
100.0 \%\end{array}$ \\
\hline & $\begin{array}{l}\text { Entry } \\
\text { Level }\end{array}$ & $\begin{array}{l}\text { Count } \\
\text { \% within Mgt } \\
\text { Level }\end{array}$ & $\begin{array}{l}4 \\
11.4 \%\end{array}$ & $\begin{array}{l}8 \\
22.9 \%\end{array}$ & $\begin{array}{l}13 \\
37.1 \%\end{array}$ & $\begin{array}{l}8 \\
22.9 \%\end{array}$ & $\begin{array}{l}2 \\
5.7 \%\end{array}$ & $\begin{array}{l}35 \\
100.0 \%\end{array}$ \\
\hline Total & & $\begin{array}{l}\text { Count } \\
\text { \% within Mgt } \\
\text { Level }\end{array}$ & $\begin{array}{l}6 \\
6.0 \%\end{array}$ & $\begin{array}{l}14 \\
14.0 \%\end{array}$ & $\begin{array}{l}39 \\
39.0 \%\end{array}$ & $\begin{array}{l}30 \\
30.0 \%\end{array}$ & $\mid \begin{array}{l}11 \\
11.0 \%\end{array}$ & $\begin{array}{l}100 \\
100.0 \%\end{array}$ \\
\hline
\end{tabular}

The information from table XVI, we can see that, $78.6 \%$ of top management which is much higher than $39.2 \%$ of the middle level management and $28.6 \%$ of the entry level management agreed to stay with their organization for their reputation even though it gives less benefit than its competitors. The relationship is also significant which is apparent in the Chi-Square Test $\left(\mathrm{X}^{\wedge} 2=16.008, \mathrm{df}=8\right.$, $\mathrm{p}=0.042$ ).

\section{Findings of Study}

The research concentrated on several factors that effects retention of the employees in the private commercial banks in Bangladesh. It has been observed that the effects of the factors are different based on the employees managerial level in their organization. For most of the factors like nonfinancial benefit, amount of bonus, the process of annual raise, increment, career growth, succession planning, process used to determine promotion and job security is major determinant of top level employee's retention where as these factors are less important for middle and entry level employees. On the other hand working condition, general security, coworker's cooperation, organizational reputation and band image is equally vital for the retention of all levels of employees.

\section{v. Conclusions}

Employee's retention can be influenced by several variables out of which management level was the concentration of the study. It has been also found that the priority of these factors differs based on management level. The banks should design their retention programs based on the level of management according to their preferences. Further research can be done based on other variable like years of experience, number of organization worked etc. To conclude it can be said that employee retention is very important parameter for organizational growth, reputation as well as for staying competitive among other competitors.

\section{References}

[1] Islam, M. M. and Hasan, M., "Employee Satisfaction on Private Sector Banks in Bangladesh: A Study on Dhaka City's Banks." Journal of Business Studies, Vol. 3, Number 1 and 2 Bangladesh Open University. ISSN: 1811-1556, 2005

[2] Branham, L.," The 7 Hidden Reasons Employees Leave", AMACOM, 2005 
[3] Knowles, M.C., "Personal and job factors affecting labour turnover" Personnel Practice Bulletin, 20(1): 25-37. 1964

[4] Annual report, Bangladesh Bank, 2014-15

[5] Meaghan, S and Nick, B, "Voluntary turnover: knowledge management-friend or foe?" J. intellect. Cap, vol. 3, no. 3, pp. 303322,2002

[6] DeMicco, FJ and Giridharan, J, "Managing employee turnover in the hospitality industry", FIU Hosp Rev, 1987, pp. 26-32.

[7] Dyke, TV \& Strick, S, "Recruitment, selection and retention of managers in the hotel and restaurant industry", FIU Hosp Rev, 1990, pp. 1-9.

[8] Cantrell, N \& Sarabakhsh, M , "Correlates of non-institutional food service turnover”, FIU Hosp Rev, 1991, pp. 52-9.

[9] Denvir A \& McMahon, F , "Labor turnover in London hotels and the cost effectiveness of preventative measures", Int. J. Hosp. Manage, vol. 11, no. 2, 1992, pp. 143-54.

[10] Hogan, JJ , "Turnover and what to do about it", The Cornell HRA Quarterly, vol. 33, no. 1, 1992, pp. 40-45.

[11] Wasmuth, WJ and Davis, SW, "Managing employee turnover: why employees leave", The Cornell HRA Quarterly, 1993, pp. 11-18.

[12] Barrows, C, "Employee turnover: implications for hotel managers", FIU Hosp Rev, 1990, pp. 24-31.

[13] Mahmud, K. and S. Idrish, "HR practice in Bangladesh: The past and future ahead", World Review of Business Research, 1(2): 71-83, 2011.

[14] Park, H.Y., J. Ofori-Dankwa and D.R. Bishop, "Organizational and environmental determinants of functional and dysfunctional turnover: Practical and research implications." Human Relations, 47(3): 353366, 1994

[15] Trevor, C.O., G. Barry and J.W. Boudreau, "Voluntary turnover and job performance: Curvilinearity and the moderating influences of salary growth and promotions." Journal of Applied Psychology, 82(1): 44-61, 1997

[16] Abbasi, S.M. and K.W. Hollman, "Turnover: The real bottom line." Public Personnel Management, 2(3): 333-342, 2000

[17] Gupta, N. and Shaw, J. "Pay fairness and Employee outcomes Exacerbation and attenuation effects of financial needs." Journal of Occupational and Organizational Psychology, Vol 74 (3), 2001 pp 22 .

[18] Guyo, W. Gakure, R and Mwangi, B. "Factors Contributing to Employee Turnover in Pharmaceuticals Companies in Kenya: A Case Study of Ranbaxy Laboratories Limited", Jomo Kenyata University of Agriculture and Technology, Nairobi, 2011

[19] Sutherland, J. , "Job-To-Job Turnover and Job-To-NonEmployment Movement: A Case Study Investigation" Personnel Review, Vol. 31 Iss: 6, 2002, p.710-721

[20] Newaz, M. K., "Employee Perception Regarding Turnover Decision -In Context of Bangladesh Banking Sector": BRAC University Journal, vol. IV, no. 2, 2007, p.67-74

[21] Miller, J.G. and K.G. Wheeler, "Unraveling the mysteries of gender differences in intentions to leave the organization" Journal of Organizational Behavour, 13(5): 465-478, 1992

[22] Quarles, R., "An examination of promotion opportunities and evaluations criteria as mechanisms for internal auditor commitment, job satisfaction and turnover intention." Managerial Issues, 6(2): 176-194. 1994

[23] Dailey, RC \& Kirk, DJ, "Distributive and procedural justice as antecedents of job dissatisfaction and intent to turnover," Human Relations, vol. 45, no. 3, pp. 305-317, 1992

[24] Shija, A.T. "Factors Contributing to Labour Turnover in the Tanzanian Public Sector the Case of Immigration Department." Dissertation for MBA, Open University of Tanzania, 2011

[25] Kilumile, V.J, "Factors Contributing To Labour Turnover in Private Schools in Tanzania, A Case Of Secondary School Teachers in Mbeya District”, Dissertation for MBA, Open University of Tanzania, 2011

[26] Hamel, G., and Breen, B. "The future of management. Boston, MA: Harvard Business School Publishing, 2007

[27] Cappelli, P., "A market driven approach to retaining talent" Harvard Business Review, 78(1): 103-111, 2000
[28] Newaz, M., Ali, T., \& Akhter, I., "Employee perception regarding turnover decision -in context of Bangladesh banking sector", 4th ed. Dhaka: BRAC University Journal, 2007.

[29] Arokiasamy, A.R.A., "A qualitative study on causes and effects of employee turnover in private sector in Malaysia." Middle-East Journal of Scientific Research, 16(11): 1532-1541, 2013

[30] Firth, L., D.J. Mellor, K.A. Moore and L. Claude, "How can managers reduce employee intention to quit" Journal of Management Psychology, 19(2): 170-187, 2007

[31] Bhatti, N., Hashmi ,M., and Raza,A., "Empirical Analysis of Job Stress on Job Satisfaction among University Teachers in Pakistan" International Business Research 3(2), 2011

[32] Ling,W., Bahron, A., and Boroh, P. "A Study on Role Stress and Job Satisfaction Among Bank Employees in Kota Kinabalu, Sabah." International Journal of Research in Management and Business Studies, 1(2), 2014.

[33] Burke, L.A. and Hsieh, C. "Optimizing fixed and variable compensation costs for employee productivity", International J ournal of Productivity and PerformanceManagement, Vol. 55 Nos 1/2, pp. 155-62., 2006.

[34] Samuel O. Michael and Chipunza Crispen, "Employee retention and turnover: Using motivational variables as a panacea”, African Journal of Business Management, Vol.3 (8), pp. 410-415, September, 2009

[35] Mahmud Khaled and Idrish Sharmin, "The Impact of Human Resource Management Practices on Turnover of Bank Employees in Bangladesh", World Review of Business Research, Vol. 1. No. 2. May 2011 Pp. 71- 83, 2011

[36] Tanchi, Khadiza Rahman, "Analyzing the Factors Influencing Employee Turnover in Private Commercial Banks in Bangladesh" Daffodil International University Journal of Business and Economics, Vol. 9, No. 1, PP. 119-130, June, 2015

[37] Sekaran, U., "Research methods for business: A skill-building approach." United Kingdom: Wiley \& Sons Ltd., 2003

About Author (s):

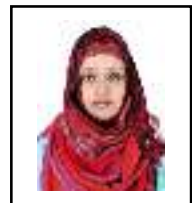

Samia Shabnaz is an Assistant Professor in the Department of Management, American International UniversityBangladesh (AIUB). She received Masters in Business Administration from AIUB, in 2008. She has more than 6 years of experience in teaching several areas of Human Resource Management and her research interest includes microcredit impact assessment, entrepreneurship development initiative, and human resource development.

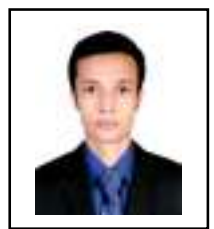

SK. Tasthekur Hossain Kowshik completed his Bachelor in Business Administration from American International University- Bangladesh with major in Human Resource Management and Marketing in September 2016. He has worked as research assistant during his internship period and currently taking preparation for his higher study. His preferred research areas include human resource management, consumer behavior and service marketing. 